\title{
Antimicrobial effect of para-alkoxyphenylcarbamic acid esters containing substituted $N$-phenylpiperazine moiety
}

\author{
Ivan Malík $^{1}$, Marián Bukovský ${ }^{2}$, Fils Andriamainty ${ }^{1}$, Jana Gališinová ${ }^{1}$ \\ ${ }^{1}$ Department of Pharmaceutical Chemistry, Faculty of Pharmacy, Comenius University, \\ Bratislava, Slovak Republic. \\ ${ }^{2}$ Department of Cell and Molecular Biology of Drugs, Faculty of Pharmacy, Comenius University, \\ Bratislava, Slovak Republic.
}

Submitted: January 18, 2012; Approved: July 23, 2012

\begin{abstract}
In current research, nine basic esters of para-alkoxyphenylcarbamic acid with incorporated 4-(4fluoro-/3-trifluoromethylphenyl)piperazin-1-yl fragment, 6i-6m and 8f-8i, were screened for their in vitro antimicrobial activity against Candida albicans, Staphylococcus aureus and Escherichia coli, respectively. Taking into account the minimum inhibitory concentration assay (MIC), as the most active against given yeast was evaluated $8 \mathrm{i}(\mathrm{MIC}=0.20 \mathrm{mg} / \mathrm{mL})$, the most lipophilic structure containing para-butoxy and trifluoromethyl substituents. Investigating the efficiency of the compounds bearing only a single atom of fluorine and appropriate para-alkoxy side chain against Candida albicans, the cut-off effect was observed. From evaluated homological series, the maximum of the effectiveness was noticed for the stucture $6 \mathrm{k}$ (MIC $=0.39 \mathrm{mg} / \mathrm{mL}$ ), containing para-propoxy group attached to phenylcarbamoyloxy fragment, beyond which the compounds ceased to be active. On the contrary, all the tested molecules were against Staphylococcus aureus and Escherichia coli (MICs $>1.00 \mathrm{mg} / \mathrm{mL}$ ) practically inactive.
\end{abstract}

Key words: phenylcarbamates, substituted $N$-phenylpiperazines, Candida albicans.

\section{Introduction}

Humans and bacteria are coevolving and both sides are engaged in a struggle to maintain the upper hand; the use of technology by our species to modify our environment and improve our quality of life $v s$. the ability of bacteria to overcome adverse conditions (Woodford, 2003). Staphylococcus aureus is a common pathogen associated with serious community and hospital acquired deseases which has been considered a major problem of Public Health for long time (Oliveira et al., 2011). It has caused a wide spectrum of infections ranging from mild impetigo and furuncules, to severe soft-issue infections, benign local skin infections, necrotizing fasciitis, pneumonia, bloodstream infections, osteomyelitis, endocarditis and other life threating infections (François et al., 2010; Lucero et al., 2009).
The genus of Escherichia includes five species and belongs to the coliform group of bacteria that colonize the intestinal tract of humans. Escherichia coli is by far the most common, as well as being the bacterial species most frequently isolated in the clinical microbiology laboratory (Maza et al., 2004). This pathogenic Gram-negative bacterium is classified into the pathotypes, i.e. groups of strains that cause a common disease using prevailing and remarkable assortments of virulence factors. It has been the most usual microorganism responsible for sepsis, urinary tract infection, nosocomial pneumonia or wound infections. Moreover, given bacterium has been also regarded as prominent cause of neonatal meningitis and gastroenteritis in developing nations (Barile, 2004; Kaper et al., 2004; Maza et al., 2004; Muhammad et al., 2011; Nataro and Kaper, 1998).

The incidence of infections caused by Candida species has been rising for decades (Miyasaka et al., 2008). In

Send correspondence to I. Malík. Department of Pharmaceutical Chemistry, Faculty of Pharmacy, Comenius University, Odbojárov 10,83232 Bratislava, Slovak Republic. E-mail: malikivan001@gmail.com. 
a survey of positive blood cultures performed in the USA, the Candida species ranked fifth in terms of overall incidence and represented the fourth most common group of nosocomial pathogens isolated from the intensive care units (Gudlaugsson et al., 2003). A similar incidence of candinemia has been also reported in European hospitals (Gudlaugsson et al., 2003; Yera et al., 2001). Human beings carry the yeast Candida albicans and other Candida species as a part of their commensal microbiota. However, in hosts predisposed to candidiasis, for example very low birth weight, immunosupressive, antibiotic, and cytotoxic therapies, diabetes mellitus, organ transplant, tumors, immunocompromised patients affected by AIDS and others, these yeasts may act as pathogens. Commensal Candida species normally inhabit in the oral, nasal and aural cavity, vaginal canal, rectum, and gastrointestinal tract of host may begin the infectious process (Diaz-Guerra et al., 1997; Hellstein et al., 1993; Miyasaka et al., 2008; Oliveira et al., 2011; Rodrigues et al., 2004).

Although a number of chemotherapeutic agents are nowadays available in therapy, concerned pathogenic microorganisms are developing resistance to them. As more resistant microorganisms continue to emerge in society, the identification of new antimicrobially effective compounds is urgently needed. The objective of the current study is to investigate in vitro susceptibility of mentioned clinically significant microbial strains to novel basic esters of paraalkoxyphenylcarbamic acid bearing variously substituted basic $N$-phenylpiperazine moiety.

\section{Materials and Methods}

\section{Chemistry}

The preparation of currently evaluated compounds, labelled as $6 \mathrm{i}-6 \mathrm{~m}$ and $8 \mathrm{f}-8 \mathrm{i}$ (Table 1), their spectral charac- teristics $\left({ }^{1} \mathrm{H}\right.$ NMR, ${ }^{13} \mathrm{C}$ NMR, IR, MS, UV/VIS $)$ as well as the elemental analyses data were already published in the literature (Malík et al., 2006; Malík et al., 2004). The determination of fundamental physicochemical parameters of these molecules, i.e. solubility profile, surface activity $\gamma$, dissociation constant $\mathrm{p} K_{\mathrm{a}}$ and lipophilicity descriptors (log $P_{\exp }$ estimated by the shake-flask method in the octan1-ol/buffer medium with $\mathrm{p} H=7.3, \log k^{\prime}$ from RP-HPLC, $R_{\mathrm{M}}$ from RP-TLC), with appropriate readouts can be found in papers (Malík et al., 2005a, 2005b).

\section{In vitro antimicrobial activity assay}

\section{Microorganisms}

The antimicrobial activity of $6 \mathrm{i}-6 \mathrm{~m}$ and $8 \mathrm{f}-8 \mathrm{i}$ was investigated against Gram-positive bacteria $S$. aureus ATCC 6538 (Micrococcaceae), Gram-negative bacteria E. coli CNCTC 377/79 (Enterobacteriaceae) and yeast $C$. albicans CCM 8186 as well. These tested bacterial strains were purchased from American Type Culture Collection (Manassas, United States of America) and Czech National Collection of Type Cultures (Prague, Czech Republic); yeast was obtained from Czech Collection of Microorganisms (Brno, Czech Republic).

\section{Culture media}

Blood agar, Endo agar and Sabouraud's agar (Imuna, Šarišské Michalany, Slovak Republic) were used for the cultivation of microorganisms listed in the previous section of this paper. Blood agar was prepared by adding $10 \%$ of defibrine sheep's blood to the melted and cooled $\left(50{ }^{\circ} \mathrm{C}\right)$ competent components.

Table 1 - The in vitro antimicrobial activity of the alkoxyphenylcarbamic acid-based compounds $6 \mathrm{i}-8 \mathrm{i}$ against selected microbial strains.

\begin{tabular}{|c|c|c|c|c|c|}
\hline \multirow[t]{2}{*}{ Entry } & \multirow[t]{2}{*}{$R^{1}$} & \multirow[t]{2}{*}{$R^{2}$} & \multicolumn{3}{|c|}{$\mathrm{MIC}(\mathrm{mg} / \mathrm{mL})$} \\
\hline & & & Staphylococcus aureus ATCC 6538 & Escherichia coli CNCTC 377/79 & Candida albicans CCM 8186 \\
\hline $6 \mathrm{i}$ & $\mathrm{CH}_{3}$ & $4^{\prime}-\mathrm{F}$ & 12.50 & 6.25 & 3.13 \\
\hline $6 \mathrm{j}$ & $\mathrm{C}_{2} \mathrm{H}_{5}$ & $4^{\prime}-\mathrm{F}$ & 12.50 & 6.25 & 1.56 \\
\hline $6 \mathrm{k}$ & $\mathrm{C}_{3} \mathrm{H}_{7}$ & $4^{\prime}-\mathrm{F}$ & 6.25 & 3.13 & 0.39 \\
\hline 61 & $\mathrm{C}_{4} \mathrm{H}_{9}$ & $4^{\prime}-\mathrm{F}$ & 12.50 & 6.25 & 0.78 \\
\hline $6 \mathrm{~m}$ & $\mathrm{C}_{5} \mathrm{H}_{11}$ & $4^{\prime}-\mathrm{F}$ & 12.50 & 6.25 & 3.13 \\
\hline $8 \mathrm{f}$ & $\mathrm{CH}_{3}$ & 3'- $-\mathrm{CF}_{3}$ & 6.25 & 6.25 & 0.78 \\
\hline $8 \mathrm{~g}$ & $\mathrm{C}_{2} \mathrm{H}_{5}$ & $3^{\prime}-\mathrm{CF}_{3}$ & 12.50 & 6.25 & 0.78 \\
\hline $8 \mathrm{~h}$ & $\mathrm{C}_{3} \mathrm{H}_{7}$ & $3^{\prime}-\mathrm{CF}_{3}$ & 12.50 & 12.50 & 0.39 \\
\hline $8 \mathrm{i}$ & $\mathrm{C}_{4} \mathrm{H}_{9}$ & $3^{\prime}-\mathrm{CF}_{3}$ & 12.50 & 12.50 & 0.20 \\
\hline
\end{tabular}




\section{Determination of minimum inhibitory concentration (MIC)}

The MIC values of investigated compounds were carried out by following the modified procedure described by Mlynarcík et al. (1981).

The respective test compounds exhibited very limited solubility in distilled water (Malík et al., 2005a, 2005b) therefore they had to be dissolved in dimethyl sulfoxide (DMSO). Standard suspension of bacteria was prepared from their $24 \mathrm{~h}$ cultures which were cultivated on a blood agar (Gram-positive bacteria) and Endo agar (Gram-negative bacteria). Standard suspension of Candida was prepared from its $48 \mathrm{~h}$ cultures cultivated on Sabouraud's agar.

Prepared suspension contained the concentration of 5 x $10^{7}$ colony forming unit (cfu) $/ \mathrm{mL}$ of bacteria and $5 \times 10^{5}$ $\mathrm{cfu} / \mathrm{mL}$ of Candida, respectively. The UV/Vis spectrophotometry was used for the determination of the microorganisms concentration, all evaluated suspensions were adjusted to the absorbance value of 0.35 at the wavelength of $540 \mathrm{~nm}$.

Suspension of microorganisms was added in amount of $5 \mu \mathrm{L}$ into the solutions of evaluated substances $(100 \mu \mathrm{L})$ and to double concentrated peptone broth medium (8\%) for bacteria or to Sabouraud's medium (12\%) for Candida. The peptone broth and Sabouraud's media were purchased from Imuna (Šarišské Michalany, Slovak Republic).

Starting concentration of prepared stock solutions was $50.00 \mathrm{mg}$ of compound per $\mathrm{mL}$ of DMSO. These stock solutions $(5 \%)$ were then serially diluted by a half and final concentrations were $25.00 ; 12.50 ; 6.25 ; 3.13 ; 1.56 ; 0.78$; $0.39 ; 0.20$ and $0.10 \mathrm{mg} / \mathrm{mL}$, respectively. In thus diluted final testing medium the antibacterial effect of present DMSO was completely lost.

The quantitative screening was performed using sterile 96-well plastic microtiter plates (with round-bottomed wells) with matching covers. Microorganisms were incubated in each well at $37{ }^{\circ} \mathrm{C}$ for $24 \mathrm{~h}$. Upon completion of this process, the volume of $5 \mu \mathrm{L}$ of evaluated suspension has been taken from each well by using transferring tool and cultured on a blood agar (S. aureus ATCC 6538), Endo agar (E. coli CNCTC 377/79) or on Sabouraud's agar ( $C$. albicans CCM 8186). Petri dishes were then incubated for $24 \mathrm{~h}$ at $37^{\circ} \mathrm{C}$.

The positive control using only an inoculation of microorganisms and the negative control using only DMSO were carried out. The DMSO and nutrient concentration remained stable in each well, only the concentration of inhibitory compound has changed. The MIC was considered to be the lowest concentration of the tested compound which inhibited the visible microbial growth (Mlynarcík et al., 1981). The MIC was dependent on the presence/absence of the culture on used solid media after the transfer of $5 \mu \mathrm{L}$ of suspension from each well. The values of MIC were reported in Table 1 in $\mathrm{mg} / \mathrm{mL}$ units.

\section{Results and Discussion}

The efficiency of investigated alkoxyphenylcarbamic acid-based compounds labelled as 6i-6m and 8f-8i, chemically 1-[3-(4-alkoxyphenylcarbamoyloxy)-2-hydroxypropyl]-4-(4-fluoro-/3-trifluoromethylphenyl)piperazinium chlorides (Table 1), was previously evaluated against tuberculous (Waisser et al., 2007b) and non-tuberculous (Waisser et al., 2007a) strains of mycobacteria.

The estimated values of MIC against Mycobacterium (M.) tuberculosis CNCTC My 331/88 of 6i-6m were in the range of $0.004-0.06 \mathrm{mg} / \mathrm{mL}$ (related to the interval of $8-125 \mu \mathrm{mol} / \mathrm{L})$ and the derivative 61 with $\mathrm{MIC}=$ $0.004 \mathrm{mg} / \mathrm{mL}(8 \mu \mathrm{mol} / \mathrm{L})$ was regarded as the most active among them. It became apparent that considered substance was even more effective than concominantly tested compounds $8 \mathrm{f}-8 \mathrm{i}$ exhibiting the MICs in the interval of 0.008 $0.009 \mathrm{mg} / \mathrm{mL}(16 \mu \mathrm{mol} / \mathrm{L}$ in all cases $)$. On the other hand, all evaluated molecules were less active (Waisser et al., 2007b) than applied standard isoniazide (INH) which showed MIC $=7.00 \times 10^{-5} \mathrm{mg} / \mathrm{mL}(0.5 \mu \mathrm{mol} / \mathrm{L})$. In addition, all the derivatives from series 8 were completely tested against M. kansasii My 235/80 (Waisser et al., 2007a), the determined MICs were in the range of 0.008 $0.02 \mathrm{mg} / \mathrm{mL}(16-32 \mu \mathrm{mol} / \mathrm{L})$. Moreover, they exhibited higher efficiency than INH (MIC > $0.03 \mathrm{mg} / \mathrm{mL}$; > $250 \mu \mathrm{mol} / \mathrm{L}$ ). Conclusions from literature (Waisser et al., 2007a, 2007b) pointed out that the MICs of inspected para-alkoxyphenycarbamic acid esters 6i-6m and $8 \mathrm{f}-8 \mathrm{i}$ were comparable with those containing meta-alkoxy substituent. Giving those results, the need of form for more extensive profile of an antimicrobial effectiveness of theabove compounds has arrised. They were screened for in vitro activity against $S$. aureus ATCC 6538 (Gram-positive bacteria, Micrococcaceae), E. coli CNCTC 377/79 (Gram-negative bacteria, Enterobacteriaceae) and $C$. albicans CCM 8186 as a representative species of yeast. The results of current antimicrobial assays are reproduced in Table 1. In general, all the tested compounds showed relatively improved anticandidacidal activity when compared to their antibacterial influencing.

All tested substances were inactive against $S$. aureus ATCC 6538, the most virulent Staphylococcus species, with the estimated MICs higher than $1.00 \mathrm{mg} / \mathrm{mL}$ regardless to the type of substitution at $N$-phenylpiperazine ring. Identical conclusions have been found in recent antimicrobial evaluation of analogical molecules containing meta-alkoxy substituent (Malík et al., 2012). Previously testing piperidinoethyl esters of ortho-, meta- and paraalkoxyphenylcarbamic acid (alkoxy=methoxy to decyloxy), Cizmárik et al. (1987) suggested that, except of the steric effects, the lipophilicity of meta- and para-alkoxy substituted positional isomers (the ortho-ones were considered practically inactive) was found as the factor conducived to their activity. More lipophilic molecules with a 
suitable position of alkoxy side string displayed relatively higher efficiency. On the contrary, current experimental readouts (Table 1) and the conclusions recently summarized by Malík et al. (2012) have pointed out that the positional meta-/para-alkoxy isomerism did not seem to be essential factor for the activity of such basic esters against S. aureus. More likely there was enzymic splitting of carbamate group in the structure of tested molecules $6 \mathrm{i}-6 \mathrm{~m}$ and $8 \mathrm{f}-8 \mathrm{i}$ giving a rise to concrete para-alkoxyanilines. In addition, expected antimicrobial activities of each paraalkoxyanilines were lower than those with longer alkoxy subtituent. These structures propably acted as the actual antimicrobial agents. Given statement was in accordance with conclusions as quoted in papers (Cizmárik and Trupl, 1978; Cizmárik et al., 1987).

From structural point of view, meta-/para-position of alkoxy side string appeared to be the crucial factor for the activity maintenance of tested compounds against $E$. coli. The estimated values of MIC related to $6 \mathrm{i}-6 \mathrm{~m}$ were higher than $1.00 \mathrm{mg} / \mathrm{mL}$, the structures $8 \mathrm{f}-8 \mathrm{i}$ were not any better off (Table 1). Previously analyzed compounds bearing meta-alkoxy substituent and 4-(4-fluorophenyl)piperazin-1-yl, 6d-6g (Malík et al., 2012), were more effective with their MICs in the interval of $0.20-0.78 \mathrm{mg} / \mathrm{mL}$ (444$1721 \mu \mathrm{mol} / \mathrm{L})$. In contrast, the molecules $8 \mathrm{c}-8 \mathrm{e}$ with metaalkoxy side string and 4-(3-trifluoromethylphenyl) piperazin-1-yl were regarded as completely inactive (Malík et al., 2012).

The explanation of the reason why the sets $6 \mathrm{i}-6 \mathrm{~m}$ and $8 \mathrm{f}-8 \mathrm{i}$ were ineffective could be due to their linearity compared to $6 \mathrm{~d}-6 \mathrm{~g}$ and $8 \mathrm{c}-8 \mathrm{e}$, respectively. On the basis of resonance theory (Carey and Sundberg, 2007; Gross and Seybold, 2000), the linearity of the compounds made the resonance (mesomeric) effect at phenyl ring which influenced their electron distribution and lipohydrophilic properties as well. Alkoxy fragments in para-position primarily acted through the resonance as electron-donating groups which were able to increase the basicity of nitrogen atom. Given substituents could distribute the negative charge towards amino moiety (part of carbamate group) facilitating its protonation. Nevertheless, described electron-donating resonance effect was countered by the electronwithdrawing inductive effect of these electronegative substituents, however, for para-position dominated positive mesomeric action (Dewick, 2006). According to formerly estimated parameters of lipophilicity, meta-alkoxy substituted structures were slightly lipophilic than corresponding para-alkoxy ones with an equal number of carbon atoms within alkoxy side string. For an illustration, the values of partition coefficient $\operatorname{logarithm}, \log P_{\exp }$, of four structures with only a single atom of fluorine, $6 \mathrm{~d}-6 \mathrm{~g}$, were in the range of 3.25-3.83, presently evaluated five compounds $6 \mathrm{i}-6 \mathrm{~m}$ exhibited the $\log P_{\exp }$ in the interval 3.12-3.78. Similarly, for three molecules bearing trifluoromethyl group, $8 \mathrm{c}-8 \mathrm{e}$, was determined the $\log P_{\exp }$ value in the range of 3.61-4.03 comparing to four currently tested compounds $8 \mathrm{f}-8 \mathrm{i}$ with their $\log P_{\exp }$ s in the area of 3.60-3.98 (Malík et al., 2005a, 2005b).

The hallmark of Gram-negative bacteria is their cell envelope, which is composed of inner (IM) and outer (OM) membrane separated by a periplasm that contains a thin peptidoglycan (or murein) layer. Although both IM and $\mathrm{OM}$ are lipid bilayers that contain proteins, dramatic differences in their structure and composition have been noticed, reflecting their different functions and the dissimilar environments that they contact. The IM is a bilayer composed of phospholipids and proteins. The periplasm comprises approximately $10 \%$ of the cell volume and is a highly viscous compartment that is occupied by soluble proteins and the peptidoglycan layer. The periplasm is an oxidizing environment, and it contains enzymes that catalyse the formation of disulphide bonds (Ruiz et al., 2006). The OM is an unusual membrane in terms of its structure and composition. Outer and inner leaflets of OM contain asymmetrically distributed lipids. In outer leaflet are virtually distributed all lipopolysaccharides (LPSs), whereas the inner leaflet has the most of the phospholipids. Due to its physical properties, the OM functions as a selective barrier that prevents the entry of many toxic molecules into the cell, a property that is crucial for bacterial survival in many environments (Ruiz et al., 2006).

As can be deduced from actual experimental data (Table 1) and from literature (Malík et al., 2012), there were several factors which could play an essential role in terms of activity of such phenylcarbamic acid esters against $E$. coli: the lipophilicity, the steric aspects (linearity or nonlinearity of molecules) and the electronic interactions induced by substituted $N$-phenylpiperazine moiety.

It could be hypothesized that meta-alkoxy substituted positional isomers antimicrobially evauated by Malík et al. (2012) more readily interacted with appropriate reaction sites in OM. In the case of currently analyzed sets $6 \mathrm{i}-6 \mathrm{~m}$ and $8 \mathrm{f}-8 \mathrm{i}$ (Table 1) the electron movements, as described above in the text, led to relatively lower level of compounds' lipophilicity which resulted in more complicated internalisation into OM. The subsequent electronic interactions, which have been possibly manifested after the incorporation into the membrane structures through the $\pi$-bonds of variously substituted $N$-phenylpiperazine fragment, could represent another contributing factor which affected the efficiency. Suggested hypothesis was also consistent with the conlusions postulated by Mlynacík et al. (1991).

The findings from previous research (Malík et al., 2012), dealing with 6d-6g and 8c-8e, have also demonstrated that these lipophilic structures could be promising especially in terms of the potency against $C$. albicans. The evaluated molecules $8 \mathrm{c}-8 \mathrm{e}$ exibited the MICs in the range of $0.10-0.20 \mathrm{mg} / \mathrm{mL}(189-399 \mu \mathrm{mol} / \mathrm{L})$, the derivatives $6 \mathrm{~d}-6 \mathrm{~g}$ were against this yeast considerably less active indi- 
cating the MIC readouts in the interval of $0.78-1.56 \mathrm{mg} / \mathrm{mL}$ (1621-3552 $\mu \mathrm{mol} / \mathrm{L})$.

The efficiency of currently inspected $6 \mathrm{i}-6 \mathrm{~m}$ and $8 \mathrm{f}-8 \mathrm{i}$ against $C$. albicans was dependent not only on para-alkoxy string length but also on the structural modification of the $\mathrm{N}$-phenylpiperazine moiety as confirmed the results in Table 1. In general, the introduction of more lipophilic, electron-withdrawing trifluoromethyl group favoured the compounds $8 \mathrm{f}-8 \mathrm{i}$ compared to those with only a single atom of fluorine $(6 \mathrm{i}-6 \mathrm{~m})$.

Anticandidacidal activity of $6 \mathrm{i}-6 \mathrm{~m}$ progressively increased with the increase in the number of carbon atoms in their side chain up to a critical point, represented by the derivative $6 \mathrm{k}$ with $\mathrm{MIC}=0.39 \mathrm{mg} / \mathrm{mL}(835 \mu \mathrm{mol} / \mathrm{L})$, beyond which the compounds ceased to be active (Table 1 ). The observed phenomena has been called the cut-off effect. The scientific groups of Balgavý and Devínsky have extensively reviewed several hypotheses of the cut-off effect in biological activities and experimental evidences supporting them (Balgavý and Devínsky, 1996; Devínsky et al., 1990). C. albicans has a multilayered cell wall composed of an outer layer of proteins glycosylated with $\mathrm{N}$ - or $O$-linked mannosyl residues and and inner skeletal layer of $\alpha$-glucans and chitin (Pinto et al., 2008). Based on the conclusions resulting from the research of above mentioned authors (Balgavý and Devínsky, 1996), for investigated compounds $6 \mathrm{i}-6 \mathrm{~m}$ were within this paper suggested several possible reasons for the manifestation of given cut-off phenomena. Firstly, that effect could be caused by a decrease in the achievable compound's concentration at the site of action due to its limited solubility. The drug partition coefficient between the aqueous solution and the site of action increased less rapidly with the increase in side chain length than the aqueous solubility decreased, until a point was reached at which the maximum achievable concentration at the site of action was significantly lower than that required to cause of the biological effect. Secondly, the physical properties in the homologous series could suddenly change at some particular substituent chain length, resulting in the different type of the interaction with the site of action. It has been also proposed that considered aspect could be a complication in the intercalation of particular compounds into (mostly) lipid bilayer. Moreover, mentioned model of action was previously outlined for locally anaesthetically effective cinchocaine homologues (Petter et al., 1970). Thirdly, following earlier experimental observations of Richards et al. (1978), degenarate pertubation of the membrane protein structure could be also taken into the consideration. In membrane proteins and at the interfaces there were different sets of hydrophobic sites of different dimensions which could accommodate different types of hydrophobic or amphiphilic molecules.

Relatively higher lipophilicity of $8 \mathrm{f}-8 \mathrm{i}$ enabled their easier internalisation into given eukaryotic pathogen which caused a pertubation of its membranes resulting in the anticandidacidal effect at relatively lower MIC values which were registered in the range of $0.20-0.78 \mathrm{mg} / \mathrm{mL}$ (367-1595 $\mu \mathrm{mol} / \mathrm{L})$. Within evaluated set, the most active compound was $8 \mathrm{i}$ (Table 1). Present findings were in accordance with conclusions already formulated (Limban et al., 2011; Malík et al., 2012). However, recently investigated meta-alkoxy substituted structures were more active than corresponding para-positional isomers, propably due to their higher lipophilicity (comparing experimentally estimated $\log P_{\exp }$ values of particular positional isomers with an equal number of carbon atoms in alkoxy side chain).

Going forward, there will be the attempt to in vitro investigate antibacterial and anticandidal activity profile of another meta-/para-alkoxyphenylcarbamic acid derivatives by the testing of new compounds containing electron-donating (methyl) functional group instead of primarily electron-withdrawing (fluoro or trifluoromethyl) ones directly attached to $N$-phenylpiperazine moiety.

\section{Conclusion}

Nine novel basic para-alkoxyphenylcarbamic acid esters bearing substituted $N$-phenylpiperazine moiety within their basic part were tested against selected Grampositive ( $S$. aureus ATCC 6538), Gram-negative (E. coli CNCTC 377/79) bacterial strain and against a yeast $(C$. albicans CCM 8186). Comparing currently and previously estimated results, it was beyond any doubt that the activity against given microorganisms was fundamentally influenced by the position of alkoxy side string attached to the aromatic ring. It became apparent that para-alkoxy substituted compounds were practically inactive against both considered bacterial strains due to the resonance mesomeric effect at phenyl ring which was involved by given substitution. The presence of such primarily electrondonating group implied an effect on the electron distribution and also lipohydrophilic properties of the target compounds.

The findings of this research also demonstrated that the activity of the molecules containing 4-(4-fluorophenyl)piperazin-1-yl within their basic part against $C$. albicans increased progressively with the elongation of alkoxy chain up to a critical point, beyond which they ceased to be active. The observed phenomena has been known as the cut-off effect. The intensity of observed inhibitory effect against given yeast reflected the lipophilicity of investigated structures carrying 4-(3-trifluoromethylphenyl)piperazin-1-yl fragment. The most lipophilic compound from whole tested series was evaluated as the most active one.

\section{Acknowledgments}

The authors are grateful to Slovak Grant Agency for Science for supporting by the grant projects VEGA No. 1/0039/12 and No. 1/0055/11. 


\section{References}

Balgavý P, Devínsky F (1996) Cut-off effects in biological activities of surfactants. Adv Colloid Interface Sci 66:23-63.

Barile FA (2004) Clinical Toxicology. Principles and Mechanisms. CRC Press, Boca Raton, p 441 p.

Carey FA, Sundberg RJ (2007) Advanced Organic Chemistry, part A: Structure and Mechanisms. $5^{\text {th }}$ edition. Springer, New York, 1222 pp.

Cizmárik J, Trupl J (1978) Antimicrobial effects of heptacaine and some intermediary products obtained during its synthesis. Folia Microbiol 23:80-81.

Cizmárik J, Trupl J, Pesák M (1987) A correlation between the antimicrobial activity to Staphylococcus aureus and selected physico-chemical parameters in the series of hydrochlorides of piperidinoethylesters of alkoxy-substituted phenyl-carbamic acids. Ceskoslov Farm 36:345-348.

Devínsky F, Kopecká-Leitmanová A, Sersen F, Balgavý P (1990) Cut-off effect in antimicrobial activity and in membrane perturbation efficiency of the homologous series of $\mathrm{N}, \mathrm{N}$-dimethylalkylamine oxides. J Pharm Pharmacol 42:790-794.

Dewick PM (2006) Essentials of organic chemistry: for students of pharmacy, medicinal chemistry and biological chemistry. $2^{\text {nd }}$ edition. John Wiley and Sons, Chichester, $710 \mathrm{pp}$.

Diaz-Guerra TM, Martinez-Suarez JV, Laguna F, RodriguesTudela JL (1997) Comparison of four molecular typing methods for evaluating genetic diversity among Candida albicans isolates from human immunodeficiency virus-positive patients with oral candidiasis. J Clin Microbiol 35:856-861.

François P, Scherl A, Hochstrasse D, Schrenzel J (2010) Proteomic approaches to study Staphylococcus aureus pathogenesis. J Proteomics 73:701-708.

Gross KC, Seybold PG (2000) Substituent effects on the physical properties and $\mathrm{p} K_{\mathrm{a}}$ of aniline. Int $\mathrm{J}$ Quantum Chem 80:1108-1115.

Gudlaugsson O, Gillespie S, Lee K, Vande Berg J, Hu J, Messer S, Herwaldt L, Pfaller MA, Diekema D (2003) Attributable mortality of nosocomial candidemia, revisited. Clin Infect Dis 37:1172-1177.

Hellstein J, Vawter-Hugart H, Fotos P, Schmid J, Soll DR (1993) Genetic similarity and phenotypic diversity of commensal and pathogenic strains of Candida albicans isolated from the oral cavity. J Clin Microbiol 31:3190-3199.

Kaper JB, Nataro JP, Mobley HLT (2004) Pathogenic Escherichia coli. Nat Rev Microbiol 2:123-140.

Limban C, Missir AV, Chirita IC, Nitulescu GM, Caproiu MT, Chifiriuc MC, Israil AM (2011) Synthesis and antimicrobial properties of new 2-((4-ethylphenoxy)methyl)benzoylthioureas. Chem Pap 65:60-69.

Lucero CA, Hageman J, Zell ER, Bulens S, Nadle J, Petit S, Gershman K, Ray S, Harrison LH, Lynfield R, Dumyati G, Townes JM, Schaffner W, Fridkin SK (2009) Evaluating the potential public health impact of a Staphylococcus aureus vaccine through use of population-based surveillance for invasive methicilin-resistant $S$. aureus disease in the United States. Vaccine 27:5061-5068.

Malík I, Bukovský M, Andriamainty F, Galisinová J (2012) Antimicrobial activity of meta-alkoxyphenylcarbamates contai- ning substituted $N$-phenylpiperazine fragment. Braz J Microbiol 43:959-965.

Malík I, Sedlárová E, Csöllei J, Andriamainty F, Kurfürst P, Vanco J (2006) Synthesis, spectral description, and lipophilicity parameters determination of phenylcarbamic acid derivatives with integrated $\mathrm{N}$-phenylpiperazine moiety in the structure. Chem Pap 60:62-67.

Malík I, Sedlárová E, Csöllei J, Racanská E, Cizmárik J, Kurfürst P (2004) Synthesis, physico-chemical properties and biological activity of 1-(4-fluorophenyl)-4-[3-(2-, 3- and 4-alkyloxyphenylcarbamoyloxy)-2-hydroxypropyl]piperazinium chlorides. Sci Pharm 72:283-291.

Malík I, Sedlárová E, Cizmárik J, Andriamainty F, Csöllei J (2005a) A study of physicochemical properties of 2-, 3-, 4-alkoxyphenylcarbamic acid derivatives with a substituted $\mathrm{N}$-phenylpiperazine moiety in the basic part. Cesslov Farm 54:235-239.

Malík I, Sedlárová E, Cizmárik J, Andriamainty F, Csöllei J (2005b) Study of physicochemical properties of 4-alkoxyphenylcarbamic acid derivatives with various substituted $N$-phenylpiperazin-1-yl moiety in the basic part of the molecule. Farm Obzor 74:211-215.

Maza LM, Pezzlo MT, Shigei JT, Peterson EM (2004) Color Atlas of Medical Bacteriology. ASM Press, Washington, $328 \mathrm{pp}$.

Miyasaka NRS, Unterkircher CS, Shimizu MT (2008) Catalase activity of different Candida species after exposition to specific antiserum. Braz J Microbiol 39:35-36.

Mlynarcík D, Bittererová J, Cizmárik J, Masárová (1991) The effect of piperidinoethylesters of $n$-alkoxyphenyl-carbamic acids on bacterial cells. Cesk Farm 40:25-28.

Mlynarcík D, Denyer SP, Hugo WB (1981) A study of the action of a bisquaternary ammonium salt, an amine oxide and an alkoxy phenylcarbamic acid ester on some metabolic functions in Staphylococcus aureus. Microbios 30:27-35.

Muhammad I, Uzma M, Yasmin B, Mehmood Q, Habib B (2011) Prevalence of antimicrobial resistance and integrons in Escherichia coli from Punjab, Pakistan. Braz J Microbiol 42:462-466.

Nataro JP, Kaper J (1998) Diarrheagenic Escherichia coli. Clin Microbiol Rev 11:142-201.

Oliveira CEV, Stamford TLM, Neto NJG, Souza EL (2010) Inhibition of Staphylococcus aureus in broth and meat broth using synergies of phenolics and organic acids. Int $\mathrm{J}$ Food Microbiol 137:312-316.

Oliveira WA, Oliveira Perreira F, Luna GCDG, Lima OI, Wanderley PA, Lima RB, Oliveira Lima E (2011) Antifungal activity of Cymbopogon winterianus Jowitt ex Bor against Candida albicans. Braz J Microbiol 42:433-441.

Petter A, Schönenberger H, Zwez W (1970) The mode of local anesthetic action of cinchocaine homologues. Arzneimittelforschung 20:1538-1542.

Pinto MR, Barreto-Bergter E, Taborda CP (2008) Glycoconjugates and polysaccharides of fungal cell wall and activation of immune system. Braz J Microbiol 39:195-208.

Richards CD, Martin K, Gregory S, Keightley CA, Hesketh TR, Smith GA, Warren GB, Metcalfe JC (1978) Degenerate perturbations of protein structure as the mechanism of anaesthetic action. Nature 276:775-779. 
Rodrigues CC, Höfling JF, Boriollo MFG, Oliveira Rodrigues JA, Azevedo RA, Gonçalves RB, Gomes LH, Tavares FCA (2004) SDS-Page and numerical analysis of Candida albicans from human oral cavity and other anatomical sites. Braz J Microbiol 35:40-47.

Ruiz N, Kahne D, Silhavy TJ (2006) Advances in understanding bacterial outer-membrane biogenesis. Nat Rev Microbiol 4:57-66.

Waisser K, Dolezal R, Cizmárik J, Malík I, Kaustová J (2007a) The antimycobacterial derivatives against potential pathogenic strains: 2-Hydroxy-3-(4-phenylpiperazin-1-yl)-propylphenylcarbamates. Sci Pharm 75:55-61.

Waisser K, Dolezal R, Cizmárik J, Malík I, Kaustová J (2007b) The potential antituberculotics of the series of 2-hydroxy- 3-(4-phenylpiperazin-1-yl)-propylphenylcarbamates. Folia Pharm Univ Carol 35-36:45-48.

Woodford N (2003) Novel agents for the treatment of resistant Gram-positive infections. Expert Opin Investig Drugs 12:117-137.

Yera H, Sendid B, Francois N, Camus D, Poulain D (2001) Contribution of serological tests and blood culture to the early diagnosis of systemic candidiasis. Eur J Clin Microbiol Infect Dis 20:864-870.

All the content of the journal, except where otherwise noted, is licensed under a Creative Commons License CC BY-NC. 